\title{
The COVID-19 Pandemic and nursing challenges: A review of the early literature
}

\author{
Mojtaba K. Danesh, Ehsan Garosi* and Hamedeh Golmohamadpour \\ Department of Occupational Health, School of Public Health, Tehran University of Medical Sciences, \\ Tehran, Iran
}

Received 20 September 2020

Accepted 12 March 2021

\begin{abstract}
.
BACKGROUND: The COVID-19 pandemic has put health systems under unprecedented pressure, challenging their workforce, especially nurses.

OBJECTIVE: The current paper presented a review of the early literature concerning emerging nursing challenges during the early stages of the COVID-19 pandemic.

METHODS: A systematic search of the published literature between January and May 2020 was carried out in Medline, Science Direct, and Google Scholar to identify relevant quantitative and qualitative studies.

RESULTS: Twenty-two original articles were retrieved, the majority of which were survey studies from China. Synthesis of the evidence resulted in four overarching themes including "being physically and mentally drained in the face of fear and uncertainty," "shortage of personal protective equipment and usability issues," "psychosomatic disturbances among nurses," and "moderators to mitigate nurses' challenges."

CONCLUSIONS: Providing care for demanding COVID-19 patients, nurses experienced a gruelling situation, during which a significant amount of psychological and physical distress was inflicted to them. However, receiving proper support from their organization and society could improve the condition substantially. Further research is required to explore the impact of the COVID-19 pandemic on nurses, especially from Western countries.
\end{abstract}

Keywords: COVID-19 pandemic, nursing, challenges, barriers

\section{Introduction}

COVID-19 appeared in Hubei Province, China at the end of 2019. The rapid spread of the virus necessitated the World Health Organization (WHO) to announce it "World Health Emergency" in late January, 2020, and immediately after, declare it as a Global Pandemic on March 12, 2020 [1]. To date, millions of new cases have been identified, and the death toll is rising every day [2,3]. In the early stages of the pandemic, despite the exceptional mobilization of people and resources to counter this phenomenon, identifying and treating a huge number of patients put

\footnotetext{
*Address for correspondence: Ehsan Garosi, Department of Occupational Health, School of Public Health, Tehran University of Medical Sciences, Tehran, Iran. E-mail: E-garosi@ alumnus.tums.ac.ir.
}

health systems under unprecedented pressure, forcing them to operate beyond their existing capacities [4]. Meanwhile, healthcare professionals, especially nurses, at the forefront of this battle were impacted the most [5].

The extent of challenges faced by nurses during the pandemic has been exceptionally broad-ranging, encompassing individual, organizational, and extraorganizational domains [6-8]. Unsurprisingly, a large body of correspondence and publications has been disseminated by scientists and health professionals to address such challenges [9-11]. However, the dissemination of countless volumes of publications in a relatively short period of time with great variability in quality and credibility has culminated in an information overload that has intensified the need for review and synthesis of more credible research 
to encapsulate the dynamics of the situation [12]. Additionally, a comprehensive identification of major challenges experienced by the nursing workforce can greatly help decision makers and officials adopt realtime strategies, both in the current context and in the future. Thus, in the current paper, we presented a review of the existing literature to illustrate what were emerging nursing challenges during the early stages of the COVID-19 pandemic. As the umbrella label of "challenges of nursing" included a wide variety of sub-concepts, and the existing literature comprised both qualitative and quantitative studies, a sufficient number of studies were allowed for inclusion to warrant a narrative review resulting in synthetic recurring themes. Potential implications for practice were subsequently discussed.

\section{Methodology}

\subsection{Search methodology and article selection}

Methodological steps by which this review study was developed were informed by Ferrari's narrative reviewing general framework [13], which puts forward steps for the identification, quality appraisal, and synthesis of pertinent studies. Accordingly, a structured literature review was carried out to investigate nurses' challenges during the early stages of the pandemic. Challenges were defined as any problem, barrier, or burden that emerged or intensified during the early stages of the pandemic. Medline, Science Direct, and Google Scholar were selected as the main databases of our search from January to May, 2020. Search combinations or strings of keywords were used as follows: "("COVID-19" OR "Coronavirus" OR "Pandemic" AND "Nurses" OR "Healthcare Worker" OR "Nursing Staff" OR "Health Personal" OR "Health Professional" OR "Care Provider" AND "Work barrier" OR "Challenge" OR "Problem" OR "Burden" OR "Impact" OR "Effect" OR "Work Condition")". We also identified additional studies from the reference lists of the identified articles. Articles were included if they met the following criteria:

1. Presenting nursing challenges during the early stages of the current pandemic and identifying factors that could mitigate such challenges

2. Being published in a peer reviewed journal

3. Being original and appropriate based on reporting primary data, validity of methods used, and clarity of results (including both credible quantitative or qualitative studies)
Our initial search yielded 986 articles, out of which 926 were excluded after reviewing their titles and abstracts with regard to the inclusion criteria. Then, the remaining articles $(n=60)$ were shared with the research team and subjected to full text review. In this step, all selected papers were critically appraised by at least two of the researchers to identify methodological shortcomings and potential biases in order to assess their credibility. Coherence of the research question or rationale for the methods of data collection and analysis were also investigated, and papers were included if there was a consensus about the acceptability of their credibility. Limitations of the included studies are summarized in Table 1 . The final assessment of the articles led to 22 articles. The flow of the article selection process is presented in Diagram 1 . The included studies were then categorized based on setting, population, methodology, key findings and limitations (Table 1).

\subsection{Analysis of the selected articles and their major themes}

The result of our literature search yielded 22 articles, out of which 21 were original except for one [14] which was in the form of an editorial letter, but succinctly followed the structure of an original article and provided credible knowledge. The majority of the papers $(n=18)$ were quantitative surveys being distributed among healthcare workers (HWs). The remaining papers were three qualitative studies and one mixed study. Regarding countries where the studies were conducted, 18 articles were from China, two articles were from Singapore, one article was from Vietnam, and one article was from Pakistan.

Given the nature of the study question and the selected literature, it was decided to conduct a narrative review. A qualitative-descriptive approach to data analysis, namely thematic analysis, was employed by the first and second authors [15]. Following the general principles of thematic analysis, authors first immersed themselves in the data by reading through the chosen literature and reflecting on them (e.g., by margin notes). Subsequently, open coding, a process in which meaningful tags are assigned to words, phrases, events, situations to make them distinguishable from the rest of the data, was conducted [16]. Then, by merging initial codes and moving up the ladder of abstraction, thematic categories were developed. Finally, emergent themes were compared and contrasted to make them as distinguishable as possible. All data were analyzed and interpreted by the 
Table 1

List of selected studies according to their setting, population, methodology, key findings and limitations

\begin{tabular}{|c|c|c|c|c|c|}
\hline $\begin{array}{l}\text { Author\& } \\
\text { Publication Year }\end{array}$ & Country\& Context & Objective(s) & $\begin{array}{l}\text { Method: Design, } \\
\text { Participants } \\
\text { \&Measurements }\end{array}$ & Key findings & Limitations \\
\hline $\begin{array}{l}\text { (Kang et al., } \\
2020 \text { ) }\end{array}$ & $\begin{array}{l}\text { China, Renmin } \\
\text { Hospital of Wuhan }\end{array}$ & $\begin{array}{l}\text { Exploring mental health } \\
\text { status of medical and } \\
\text { nursing staff }\end{array}$ & $\begin{array}{l}\text { Quantitative / } 944 \mathrm{HWs} \text { / } \\
\text { questionnaire: (PHQ-9), } \\
\text { (GAD-7), (ISI), (IES-R) }\end{array}$ & $\begin{array}{l}\text { The prevalence of mental } \\
\text { health disturbance among } \\
\text { medical nurses was } 36.9 \% \\
\text { subthreshold, } 34.4 \% \text { mild, } \\
22.4 \% \text { moderate, and } \\
6.2 \% \text { severe. }\end{array}$ & $\begin{array}{l}\text { - Self-reporting } \\
\text { questionnaire } \\
\text { - Sample size }\end{array}$ \\
\hline (Chew et al., 2020) & $\begin{array}{l}\text { Singapore \& India/ } 5 \\
\text { major hospitals }\end{array}$ & $\begin{array}{l}\text { Investigating the } \\
\text { association between } \\
\text { psychological outcomes } \\
\text { and physical symptoms } \\
\text { among HWs }\end{array}$ & $\begin{array}{l}\text { Quantitative / 906HWs/ } \\
\text { Self-made, (DASS-21) } \\
\text { and (IES-R) } \\
\text { questionnaires }\end{array}$ & $\begin{array}{l}10.6 \%, 15.7 \%, 5.2 \% \text { and } \\
7.4 \% \text { of healthcare } \\
\text { workers reported } \\
\text { depression, stress, anxiety } \\
\text { and PTSD respectively. }\end{array}$ & $\begin{array}{l}\text { - Self-made questionnaire } \\
\text { - Lack of validity check of } \\
\text { reported symptoms } \\
\text { - Socioeconomic status and } \\
\text { education level were not } \\
\text { recorded }\end{array}$ \\
\hline $\begin{array}{l}\text { (Huang and } \\
\text { Zhao, 2020) }\end{array}$ & $\begin{array}{l}\text { China / Selected } \\
\text { hospitals }\end{array}$ & $\begin{array}{l}\text { Assessing the mental health } \\
\text { burden of Chinese public } \\
\text { during the outbreak, and } \\
\text { to explore the potential } \\
\text { influential factors }\end{array}$ & $\begin{array}{l}\text { Quantitative/ } 603 \text { People, } \\
\text { and } 183 \text { HWs/ } \\
\text { questionnaire: COVID-19 } \\
\text { related (GAD-7), } \\
\text { (CES-D), (PSQI) }\end{array}$ & $\begin{array}{l}\text { Prevalence of anxiety, } \\
\text { depressive symptoms, and } \\
\text { sleep disorders were } \\
34.0 \%, 18.1 \% \text {, and } \\
18.1 \% \text {, respectively. }\end{array}$ & $\begin{array}{l}\text { - Unable to assess an } \\
\text { individual's } \\
\text { psychological condition } \\
\text { before the outbreak }\end{array}$ \\
\hline $\begin{array}{l}\text { (Lai et al., } \\
2020 \text { ) }\end{array}$ & $\begin{array}{l}\text { China/ } 34 \text { selected } \\
\text { hospitals }\end{array}$ & $\begin{array}{l}\text { Assessing the magnitude of } \\
\text { mental health outcomes } \\
\text { and associated factors } \\
\text { among health care } \\
\text { workers }\end{array}$ & $\begin{array}{l}\text { Quantitative /764 nurses, } \\
493 \\
\text { physicians/questionnaire: } \\
\text { (PHQ-9), (GAD-7), (ISI) } \\
\text { and (IES-R) }\end{array}$ & $\begin{array}{l}\text { Depression, anxiety, } \\
\text { insomnia, and distress } \\
\text { were } 50.4 \%, 44.6 \% \text {, } \\
34.0 \% \text {, and } 71.5 \% \text {, } \\
\text { respectively. }\end{array}$ & - Response rate bias \\
\hline $\begin{array}{l}\text { (Xiao et al., } \\
2020 \text { ) }\end{array}$ & $\begin{array}{l}\text { China/ selected } \\
\text { hospitals in several } \\
\text { provinces }\end{array}$ & $\begin{array}{l}\text { Determine the effects of } \\
\text { social support on sleep } \\
\text { quality and function of } \\
\text { medical staff who treated } \\
\text { patients with COVID-19 }\end{array}$ & $\begin{array}{l}\text { Quantitative/180 HWs/ } \\
\text { questionnaire:Self-Rating } \\
\text { Anxiety Scale (SAS), } \\
\text { (GSES), (SASR), (PSQI), } \\
\text { and (SSRS) }\end{array}$ & $\begin{array}{l}\text { Social support positively } \\
\text { influenced self-efficacy } \\
\text { and sleep quality. } \\
\text { Anxiety and stress } \\
\text { negatively affected } \\
\text { self-efficacy sleep quality, } \\
\text { social support. }\end{array}$ & $\begin{array}{l}\text { - Sample size } \\
\text { - Causal inference from a } \\
\text { cross-sectional study } \\
\text { should be interpreted } \\
\text { cautiously }\end{array}$ \\
\hline $\begin{array}{l}\text { (Cai et al., } \\
2020 \text { ) }\end{array}$ & $\begin{array}{l}\text { China/ Selected } \\
\text { hospitals in Hunan } \\
\text { province }\end{array}$ & $\begin{array}{l}\text { Investigating the } \\
\text { psychological impact and } \\
\text { coping strategies of } \\
\text { frontline medical staff }\end{array}$ & $\begin{array}{l}\text { Quantitative/534 HWs/ } \\
\text { Self-made questionnaire }\end{array}$ & $\begin{array}{l}35.5 \%, 38.7 \% \text {, and } 10 \% \text { of } \\
\text { nursesfelt slightly, } \\
\text { moderately and highly } \\
\text { nervous or frighten in } \\
\text { their ward, respectively. }\end{array}$ & $\begin{array}{l}\text { - Limited validity of a } \\
\text { self-made survey } \\
\text { - Cross-sectional study } \\
\text { design } \\
\text { - Sample size } \\
\text { - Time constraints }\end{array}$ \\
\hline
\end{tabular}


Table 1

\begin{tabular}{|c|c|c|c|c|c|}
\hline $\begin{array}{l}\text { Author\& } \\
\text { Publication Year }\end{array}$ & Country\& Context & Objective(s) & $\begin{array}{l}\text { Method: Design, } \\
\text { Participants } \\
\text { \&Measurements } \\
\end{array}$ & Key findings & Limitations \\
\hline $\begin{array}{l}\text { (Mo et al., } \\
2020 \text { ) }\end{array}$ & $\begin{array}{l}\text { China/ Guangxi } \\
\text { hospital }\end{array}$ & $\begin{array}{l}\text {-Investigating the work } \\
\text { stress among nurses } \\
\text {-Exploring the relevant } \\
\text { influencing factors. }\end{array}$ & $\begin{array}{l}\text { Quantitative/180 nurses/ } \\
\text { questionnaires: (SOS) and } \\
\text { (SAS) }\end{array}$ & $\begin{array}{l}\text { Nurses stress and anxiety } \\
\text { score }(\text { Mean } \pm \text { Sd) were } \\
(39.91 \pm 12.92) \text { and } \\
(32.19 \pm 7.56) \text {. }\end{array}$ & $\begin{array}{l}\text { - Sample size } \\
\text { - Cross-sectional study } \\
\text { design } \\
\text { - Time constraints }\end{array}$ \\
\hline $\begin{array}{l}\text { (Wu et al., } \\
2020 \text { ) }\end{array}$ & $\begin{array}{l}\text { Hubei Cancer Hospital } \\
\text { in China }\end{array}$ & $\begin{array}{l}\text { Comparing the frequency } \\
\text { of burnout between } \\
\text { physicians and nurses in } \\
\text { frontline wards and those } \\
\text { working in usual wards }\end{array}$ & $\begin{array}{l}\text { Quantitative/ } 220 \mathrm{HWs} / \\
\text { Maslach Burnout } \\
\text { questionnaire }\end{array}$ & $\begin{array}{l}\text { Burnout for front line vs. } \\
\text { other wards was (13\% vs. } \\
39 \% \text { ) }\end{array}$ & $\begin{array}{l}\text { - Sample size } \\
\text { - Selection bias and low } \\
\text { response rate }\end{array}$ \\
\hline $\begin{array}{l}\text { (Saqlain } \\
\text { et al., } \\
\text { 2020) }\end{array}$ & $\begin{array}{l}\text { Pakistan/ selected HWs } \\
\text { in hospitals }\end{array}$ & $\begin{array}{l}\text { Identifying the current } \\
\text { status of knowledge, } \\
\text { attitude and practice } \\
\text { regarding COVID-19 } \\
\text { among HCWs in Pakistan. }\end{array}$ & $\begin{array}{l}\text { Quantitative/414 HWs/ } \\
\text { KAP questionnaire }\end{array}$ & $\begin{array}{l}\text {-HWs have good } \\
\text { knowledge ( } 93.2 \%, \\
N=386) \text {, a positive } \\
\text { attitude [mean } 8.43 \\
\text { (standard deviation } 1.78)] \\
\text { and good practice }(88.7 \%, \\
N=367 \text { ) regarding } \\
\text { COVID-19 }\end{array}$ & $\begin{array}{l}\text { - Time constraints } \\
\text { - Online survey }\end{array}$ \\
\hline $\begin{array}{l}\text { (Zhu et al., } \\
\text { 2020) }\end{array}$ & China/ Tongji Hospital & $\begin{array}{l}\text { Assessing the immediate } \\
\text { psychological impact of } \\
\text { pandemic on HWs }\end{array}$ & $\begin{array}{l}\text { Quantitative/5062 } \\
\text { HWs/questionnaire:(IES- } \\
\text { R), (PHQ-9) and, } \\
\text { (GAD-7) }\end{array}$ & $\begin{array}{l}29.8 \%, 13.5 \%, \text { and } 24.1 \% \\
\text { of healthcare workers } \\
\text { reported stress, } \\
\text { depression and anxiety } \\
\text { symptoms, respectively. }\end{array}$ & \\
\hline $\begin{array}{l}\text { (Shi et al., } \\
2020)\end{array}$ & $\begin{array}{l}\text { China/ In two selected } \\
\text { mental health centres }\end{array}$ & $\begin{array}{l}\text { Assessing the knowledge } \\
\text { and attitudes of medical } \\
\text { staff }\end{array}$ & $\begin{array}{l}\text { Quantitative/141 } \\
\text { psychiatrists and } 170 \\
\text { psychiatric nurses/ KAP } \\
\text { 33-item survey }\end{array}$ & $\begin{array}{l}89.51 \% \text { of the medical staff } \\
\text { of the psychiatric } \\
\text { hospitals studied had } \\
\text { extensive knowledge of } \\
\text { COVID- } 19 \text {, and } 64.63 \% \\
\text { of them received the } \\
\text { relevant training. }\end{array}$ & $\begin{array}{l}\text { - Selection bias } \\
\text { - Sample size } \\
\text { - Results are based on a } \\
\text { self-reported } \\
\text { questionnaire }\end{array}$ \\
\hline $\begin{array}{l}\text { (Giao et al., } \\
2020)\end{array}$ & $\begin{array}{l}\text { Vietnam/HWs in } \\
\text { Vietnam }\end{array}$ & $\begin{array}{l}\text { Assessing the healthcare } \\
\text { workers knowledge and } \\
\text { attitude toward } \\
\text { coronavirus disease }\end{array}$ & $\begin{array}{l}\text { Quantitative/327 HWs/ } \\
\text { self-made questionnaire }\end{array}$ & $\begin{array}{l}\text {-Knowledge and attitude of } \\
\text { participants were } \\
\text { recorded as } 88.4 \% \text {. }\end{array}$ & $\begin{array}{l}\text { - Sample size } \\
\text { - Limited validity of a } \\
\text { self-made survey }\end{array}$ \\
\hline $\begin{array}{l}\text { (Zhou., } \\
2020)\end{array}$ & $\begin{array}{l}\text { China/in Henan } \\
\text { province }\end{array}$ & $\begin{array}{l}\text { Investigating KAP } \\
\text { concerning patients } \\
\text { infected with COVID-19 } \\
\text { among HWs }\end{array}$ & $\begin{array}{l}\text { Quantitative/1357 HWs } \\
\text { across } 10 \text { hospitals/ A } \\
\text { cross-sectional survey }\end{array}$ & $\begin{array}{l}89 \% \text { of HWs had sufficient } \\
\text { knowledge of COVID-19, } \\
\text { more than } 85 \% \text { feared } \\
\text { self-infection with the } \\
\text { virus, and } 89.7 \% \text { followed } \\
\text { correct practices } \\
\text { regarding COVID-19. }\end{array}$ & $\begin{array}{l}\text { - Measurement of KAP } \\
\text { may be imprecise due to } \\
\text { the limited number of } \\
\text { items }\end{array}$ \\
\hline
\end{tabular}




\begin{tabular}{|c|c|c|c|c|c|}
\hline $\begin{array}{l}\text { (Liu et al., } \\
2020 \text { ) }\end{array}$ & $\begin{array}{l}\text { China/in different } \\
\text { regions in China }\end{array}$ & $\begin{array}{l}\text { Investigating anxiety } \\
\text { among HWs }\end{array}$ & $\begin{array}{l}\text { Quantitative/512 } \\
\text { Healthcare/ questionnaire: } \\
\text { (SAS) }\end{array}$ & $\begin{array}{l}\text { The prevalence of anxiety } \\
\text { was } 12.5 \% \text {, suffering } \\
\text { from mild } 10.35 \% \text {, } \\
\text { moderate } 1.36 \% \text {, and } \\
\text { severe anxiety } 0.78 \% \text {. }\end{array}$ & $\begin{array}{l}\text { - A selective bias in } \\
\text { non-randomly data } \\
\text { collection } \\
\text { - A cross-sectional design }\end{array}$ \\
\hline $\begin{array}{l}\text { (Yifan et al., } \\
2020 \text { ) }\end{array}$ & China/ in Wuhan & $\begin{array}{l}\text { Investigating the symptoms } \\
\text { and causes of somatic } \\
\text { disordersamong ICU } \\
\text { nurses treating COVID-19 } \\
\text { pneumonia }\end{array}$ & $\begin{array}{l}\text { Quantitative/140 ICU } \\
\text { nurses/ (ICF) } \\
\text { questionnaire/ }\end{array}$ & $\begin{array}{l}\text { Five major symptoms were } \\
\text { chest discomfort and } \\
\text { palpitation }(31.4 \%) \text {, } \\
\text { dyspnea }(30.7 \%) \text {, nausea } \\
(21.4 \%) \text {, headache } \\
(19.3 \%) \text {, and dizziness } \\
(17.9 \%) \text {. }\end{array}$ & $\begin{array}{l}\text { - Selection bias } \\
\text { - Low response rate }\end{array}$ \\
\hline $\begin{array}{l}\text { (Lan et al., } \\
2020 \text { ) }\end{array}$ & $\begin{array}{l}\text { China/tertiary hospitals } \\
\text { in Hubei }\end{array}$ & $\begin{array}{l}\text { Estimating the prevalence, } \\
\text { clinical features, and risk } \\
\text { factors of skin damage } \\
\text { among HWs }\end{array}$ & $\begin{array}{l}\text { Quantitative/ } 542 \text { physicians } \\
\text { and nurses/self-made } \\
\text { online questionnaires }\end{array}$ & $\begin{array}{l}\text { The skin damage caused by } \\
\text { enhanced } \\
\text { infection-prevention } \\
\text { measures was } 97.0 \% \text { ( } 526 \\
\text { of } 542 \text { ). }\end{array}$ & $\begin{array}{l}\text { - Possible risk factors in } \\
\text { daily life were not } \\
\text { included } \\
\text { - Limited validity of a } \\
\text { self-made survey }\end{array}$ \\
\hline $\begin{array}{l}\text { (Jin et al., } \\
2020 \text { ) }\end{array}$ & $\begin{array}{l}\text { China/ Tertiary acute } \\
\text { care hospital in } \\
\text { Wuhan }\end{array}$ & $\begin{array}{l}\text { Identifying Influencing } \\
\text { factors, psychosocial } \\
\text { changes, and management } \\
\text { procedures for COVID-19 } \\
\text { infected HWs }\end{array}$ & $\begin{array}{l}\text { Qualitative/ } 105 \\
\text { HWs/Validated } \\
\text { questionnaire }\end{array}$ & $\begin{array}{l}\text { - } 87 \text { cases }(84.5 \%) \text { thought } \\
\text { they were infected in } \\
\text { working environment in } \\
\text { hospital. }(41.8 \%) \text { thought } \\
\text { HWs' infection was } \\
\text { related to protective } \\
\text { equipment. } 88.3 \% \text { of staff } \\
\text { experienced } \\
\text { psychological changes } \\
\text { during their isolation } \\
\text { period }\end{array}$ & $\begin{array}{l}\text { - Memory biases among } \\
\text { participants }\end{array}$ \\
\hline $\begin{array}{l}\text { (Liu et al., } \\
2020 \text { ) }\end{array}$ & $\begin{array}{l}\text { China/in Hubei } \\
\text { province }\end{array}$ & $\begin{array}{l}\text { Describing the experiences } \\
\text { of HWs in the early stages } \\
\text { of the outbreak }\end{array}$ & $\begin{array}{l}\text { Qualitative/ } 9 \text { nurses and } 4 \\
\text { physicians/ Telephone } \\
\text { interviews }\end{array}$ & $\begin{array}{l}\text { Three major themes } \\
\text { regarding responsibility, } \\
\text { challenges and resilience } \\
\text { were explored. }\end{array}$ & $\begin{array}{l}\text { - Interview by telephone. } \\
\text { - The semi-structured } \\
\text { interview guide was not } \\
\text { piloted. } \\
\text { - Sample size }\end{array}$ \\
\hline $\begin{array}{l}\text { (Sun et al., } \\
2020 \text { ) }\end{array}$ & $\begin{array}{l}\text { China/Hospital of } \\
\text { Henan University }\end{array}$ & $\begin{array}{l}\text { Exploring the psychology } \\
\text { of nurses caring for } \\
\text { COVID-19 patients. }\end{array}$ & $\begin{array}{l}\text { Qualitative/20 nurses/ } \\
\text { Interview }\end{array}$ & $\begin{array}{l}\text {-Negative emotions present } \\
\text { in early stage consisting } \\
\text { of fatigue } \\
\text {-Growth under pressure } \\
\text {-Positive emotions occurred } \\
\text { simultaneously with } \\
\text { negative emotions. }\end{array}$ & $\begin{array}{l}\text { - Sample size } \\
\text { - Time constraints }\end{array}$ \\
\hline
\end{tabular}


Table 1

(Continued)

\begin{tabular}{|c|c|c|c|c|c|}
\hline $\begin{array}{l}\text { Author\& } \\
\text { Publication Year }\end{array}$ & Country\& Context & Objective(s) & $\begin{array}{l}\text { Method: Design, } \\
\text { Participants } \\
\& \text { Measurements }\end{array}$ & Key findings & Limitations \\
\hline $\begin{array}{l}\text { (Yin and } \\
\text { Zeng.,2020) }\end{array}$ & $\begin{array}{l}\text { China/Tertiary general } \\
\text { hospital in Wuhan }\end{array}$ & $\begin{array}{l}\text { Exploring the psychological } \\
\text { needs of nurses caring for } \\
\text { patients with (COVID-19) }\end{array}$ & $\begin{array}{l}\text { Qualitative/10 nurses/ A } \\
\text { semi-structured, personal, } \\
\text { in-depth interview }\end{array}$ & $\begin{array}{l}\text {-Relatedness needs } \\
\text { consisted interpersonal } \\
\text { needs, humanistic concern } \\
\text { needs, and family needs } \\
\text {-Growth needs were } \\
\text { reflected as a strong need } \\
\text { for knowledge }\end{array}$ & $\begin{array}{l}\text { - Time constraints for data } \\
\text { collection and data } \\
\text { analysis } \\
\text { - Sample size }\end{array}$ \\
\hline $\begin{array}{l}\text { (Ong et al., } \\
2020)\end{array}$ & $\begin{array}{l}\text { Singapore/In the } \\
\text { National University } \\
\text { Hospital }\end{array}$ & $\begin{array}{l}\text { Determining } \\
\text { PPE-associated problems } \\
\text { and its impact on HWs }\end{array}$ & $\begin{array}{l}\text { Quantitative/ } 158 \mathrm{HWs} / \\
\text { self-made questionnaire } \\
\text { was used }\end{array}$ & $\begin{array}{l}\text { Pre-existing primary } \\
\text { headache combined PPE } \\
\text { usage for }>4 \text { hours per } \\
\text { day associated with } d e \\
\text { novo } \text { PPE-associated } \\
\text { headaches }\end{array}$ & $\begin{array}{l}\text { - Using self-administrative } \\
\text { questionnaire } \\
\text { - Other risk factors for } \\
\text { headache were not } \\
\text { considered }\end{array}$ \\
\hline $\begin{array}{l}\text { (Zhang et al., } \\
\text { 2020) }\end{array}$ & $\begin{array}{l}\text { China/Several hospital } \\
\text { in China }\end{array}$ & $\begin{array}{l}\text { Analysing the actual work } \\
\text { hours and preferred work } \\
\text { hours per shift of nurses } \\
\text { and exploring influencing } \\
\text { factors on the nurses who } \\
\text { reported the preferred } \\
\text { work hours. }\end{array}$ & $\begin{array}{l}\text { Mixed/109 nurses } \\
\text { responded to a } \\
\text { self-madequestionnaire } \\
\text { and } 44 \text { nurses completed } \\
\text { the open-ended questions. }\end{array}$ & $\begin{array}{l}\text { The actual work hours per } \\
\text { shift among frontline } \\
\text { nurses exceeded the } \\
\text { nurses reported preferred } \\
\text { work hours. The } \\
\text { influencing factors for } \\
\text { preferred work hours } \\
\text { were circumstances, PPE, } \\
\text { the physical and } \\
\text { emotional needs of } \\
\text { nurses, safety needs of } \\
\text { nurses and work intensity. }\end{array}$ & $\begin{array}{l}\text { - A cross-sectional design } \\
\text { - Using a self-designed } \\
\text { questionnaire } \\
\text { - Time constraints } \\
\text { Actual work and preferred } \\
\text { work hours were } \\
\text { measured by subjective } \\
\text { way. }\end{array}$ \\
\hline
\end{tabular}

Abbreviations: (GAD): Generalized Anxiety Disorder, (PHQ): Patient Health Questionnaire, (ISI): Insomnia Severity Index, (IES-R): Event Scale-Revised, (DASS-21): Depression Anxiety Stress Scales, (CES-D): Center for Epidemiology Scale for Depression, (PSQI): Pittsburgh Sleep Quality Index, (SAS): Self-Rating Anxiety Scale, (GSES): General Self- Efficacy Scale, (SASR): Stanford Acute Stress Reaction, (SSRS): Social Support Rate Scale, (SOS): Stress Overload Scale, 
first and second authors independently. However, final acceptance of codes and themes was determined by consensus, before which open discussions were held to discuss codes, solve disagreements, and refine and re-conceptualize themes. As a result, four major themes were identified as below: 1. Being physically and mentally drained in the face of fear and uncertainty, 2. Shortage of personal protective equipment and usability issues, 3. Psychosomatic disturbances among nurses, and 4. Moderators to mitigate nurses' challenges

\section{Results}

\subsection{Being physically and mentally drained in the face of fear and uncertainty}

The pandemic put health systems, especially nurses, under enormous pressure in an unprecedented condition $[6,7,17,18]$. According to Liu et al. [6], it was a "completely new context" where nurses were "overwhelmed and exhausted by the workload and protective gear". Saqlain et al. stated that overcrowding in emergency wards became a major barrier [19], and Zhou et al. reported that about half of their nurses were overworked (working more than 8 hours a day) and significantly fatigued [17]. In the same vein, Zhang et al. showed that the actual working hours of frontline nurses considerably exceeded their preferred working hours, also Mo et al. concluded this as a major factor affecting nurses' perceived stress [18, $20]$.

Nursing of COVID-19 patients was a challenge rarely faced before due to its characteristics of rapid deterioration, pathogenicity, and high transmission rate [21]. It was stated that the condition of critically ill patients with the disease was highly changeable, and that they often had more than one complication leading to multiple organ failure [6]. Sun et al. demonstrated that nursing in this emerging situation was characterized with high-intensity work and fatigue [7]. In fact, it was "managing both mundane and extraordinarily difficult situations" [6], which became extremely physically and emotionally demanding when combined with excessive working hours (which was normal during the pandemic) [20]. Liu et al. argued that since many COVID-19 patients possessed severe anxiety, one of the nursing challenges during the pandemic was to support the patients emotionally and "treat the patient, not just the disease", according to nurses [6]. Additionally, Cai et al. found that the majority of nurses realized "see your infected patient die in front of you" as highly stressful and a difficult emotional burden [8].

Due to the highly transmittable nature of the disease, studies showed that nurses faced uncertainty and limited interpersonal relationship, mainly due to the fear of infection [6]. Cai et al. showed that almost 80 percent of HWs, the majority of whom were nurses, were highly or moderately concerned with mistakes or inattention leading to infection of others or themselves [8]. As a result, it is not surprising to observe that once mundane events in intensive care units such as sputum splash, urine/feces splash, and urine/feces clearance perceived to be risk factors for many psychosomatic symptom clusters [22]. On the other hand, Yin and Zeng in their study found that a major theme was relatedness which pointed to disturbed interpersonal relationships of nurses, as declared by a frontline nurse: "I miss the days when we could talk to each other without face masks." [23].

\subsection{Shortage of personal protective equipment and usability issues}

A major theme among the reviewed papers was related to issues regarding PPE as well as their prominent shortage and usability shortcomings $[6,8,23$, 24]. Yin and Zeng [23] showed that "need for safety" and "everyday availability of PPE" were major concerns for frontline nurses. Liu et al., in their qualitative study explored that "sufficient protective supplies are the most significant" was a recurring theme [6]. Similarly, Cai et al. reported that almost 90 percent of their HWs, the majority of whom were nurses, had often faced shortage of medical equipment and resources including PPE. In the face of such scarcity, the same survey showed that adequate protective equipment provided by hospitals was the most significant motivating factor for HWs [8].

Since the start of the pandemic, there has been a significant increase in the frequency of PPE usage. Ong et al. reported that nurses had to wear both masks and protective eyewear for an average of 5.7 hours per day, which was even more drastic in isolation wards. Such prolong exposure to protective clothing introduced considerable challenges to nursing [24]. Liu et al. reported that their nurses were overwhelmed and exhausted due to serving long hours in protective suits without being able to have essential breaks [6]. Zhang et al. showed that another difficulty of using PPE was spending a lot of time wearing and removing it, making it a challenge to have breaks. 
Moreover, they showed that fog appearance on goggles blocked nurses' line of sight [20]. Consequently, studies showed that PPE shortage on the one hand and low usability of personal equipment on the other hand put nurses in an uncomfortable situation, impacting their health and performance $[20,24]$.

\subsection{Psychosomatic disturbances among nurses}

Among the 22 original articles, the most notable theme was psychosomatic disturbances among nurses, as was reflected in 16 of the them (two qualitative and 14 quantitative studies). The theme shows a significant trend in the published articles. Moreover, out of the 22 articles, 12 focused on mental health problems and five investigated physical or somatic distress. Among them, only one paper mentioned both physical and mental issues simultaneously.

\subsubsection{Psychological disturbances among nurses}

Based on the reviewed articles (10 survey and two qualitative interview studies), fear, discomfort, stress, anxiety, insomnia, and depression were the most prevalent psychological disturbances among nurses, demonstrating how they truly felt about facing the

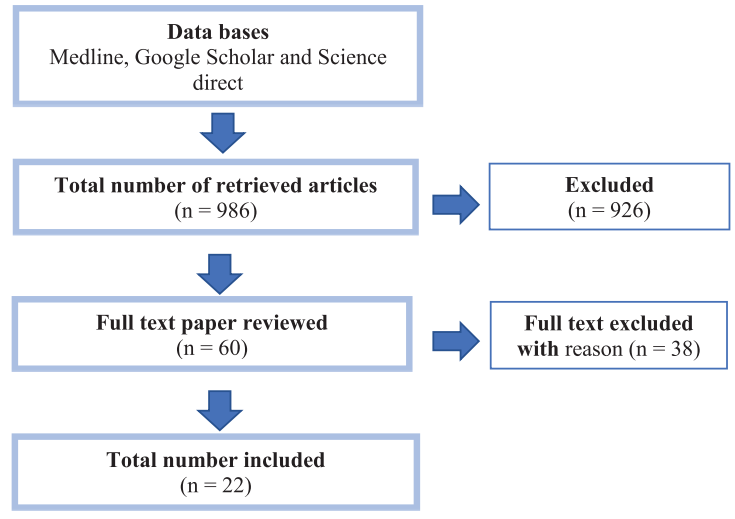

Fig. 1. The flow diagram of the search strategy.

pandemic $[7,18,21,25-30]$. The most investigated concept was anxiety $(n=9)$ whereas burnout was the least mentioned symptom. Figure 2 illustrates the frequency of the examined psychological disturbances cited in the reviewed literature.

Two qualitative studies explored experiences of nurses caring for COVID-19 patients by utilizing a phenomenological approach $[6,7]$. Sun et al. showed that negative emotions were dominant in frontline

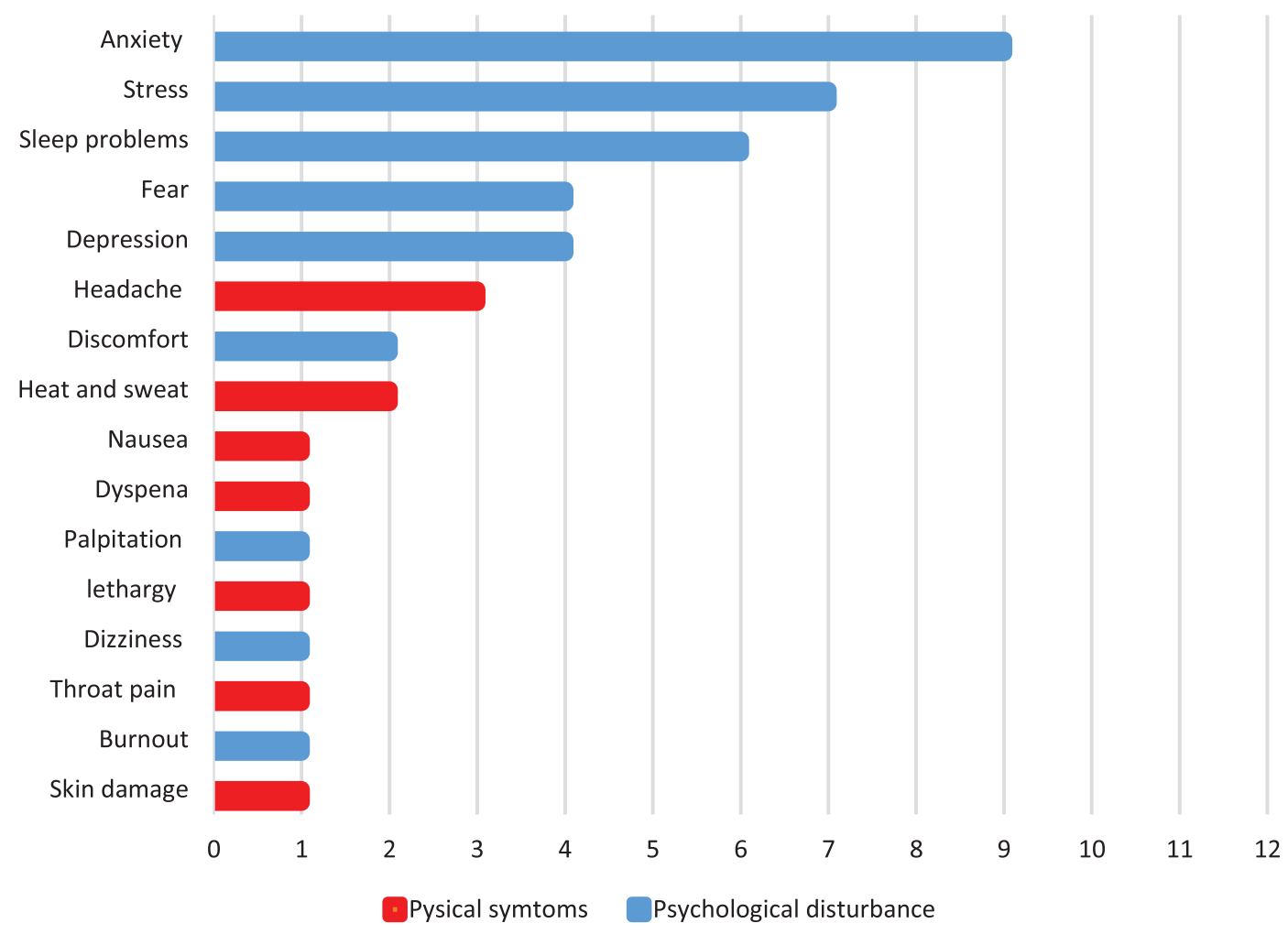

Fig. 2. The frequency of the publications in terms of psychosomatic disturbances during the COVID-19 pandemic. 
nurses including fear and anxiety, as a result of extreme concern over themselves, their patients, and family members, which, in turn, led to fatigue, helplessness, and discomfort [7]. In parallel, Liu et al. explored that fear and anxiety for family members was a recurring theme among nurses [31]. Accordingly, a nurse quoted, "I lived at home. I was anxious, wondering if I brought the virus home and spread it to my family. My child is so young, what if she is infected?" [6]. Supporting the results of the qualitative studies, a survey among HWs showed that almost half of nurses were highly or moderately frightened or nervous while working in their work unit, which was significantly higher compared to doctors and medical technicians $(P<.05)[8]$.

Surveys investigating psychological distress among HWs produced a significant body of the literature, the majority of which were carried out in China (9 out of 10). Anxiety and depression were the prominent psychological symptoms that were endemic among HWs and nurses, in particular. Frontline HWs involved in direct diagnosis, treatment, and care of COVID-19 patients experienced higher depression (OR, 1.52, $P<.01$ ), anxiety (OR, 1.57, $P<.001$ ), insomnia (OR, 2.97, $P<.001$ ), and distress $(\mathrm{OR}, 1.60, P<0.001)$ [28]. Similarly, in a study by Liu et al., the prevalence of anxiety among HWs was found to be $12.5 \%$, and frontline staff reported higher anxiety scores [21]. Furhter, a study among Chinese nurses revealed that the prevalence of mild, moderate, and severe depression levels was $34.4 \%$, $22.4 \%$, and $6.2 \%$, respectively [32]. Moreover, a study in Wuhan showed that psychological disturbances affected healthy nurses, and that most of infected nurses experienced psychological stress or emotional changes during their isolation and the period after being diagnosed positive with COVID-19 [30].

In contrast to the abovementioned literature, a survey of 191 medical staff including physicians and nurses from Hubei showed that first-line workers had a lower frequency of burnout (13\% vs. 39\%; $P<0.000)$ and were less worried about being infected with coronavirus compared to those working in other units. They argued that there could be multiple reasons for their findings, including deeper sense of personal achievement among frontline staff, greater access to more timely and accurate information, or even, greater control over their job due to direct care for COVID-19 patients [33].

Furthermore, the literature revealed that perceived nursing psychological challenges were buffered through many factors including personal and family safety [8], work experiences, age and past medical history [25], concern for the patient and family members [7], sleep quality [29], distance from the infected patient [21], and having children and work hours [18].

\subsubsection{Physical distress among nurses}

Five papers (four quantitative surveys and one qualitative survey) investigated physical symptoms among nurses. Figure 2 illustrates the frequency of observed physical symptoms cited in the relevant studies. According to the qualitative study, heating and sweating were among challenges experienced by nurses while working in frontlines, resulting from wearing non-user-friendly PPE. According to a nurse: "I sweat after wearing the protective gear for a while or when I move, such as turning patients. Then I feel clammy." [6].

On the quantitative side, Ong et al. focused on the adverse outcomes of long exposure to PPE during the COVID-19 pandemic [24]. They showed that out of 158 participants, $128(81.0 \%)$ reported de novo PPE-associated headaches developed mostly due to exacerbation of their preexisting headache disorders. Similarly, Yifan et al. reported a high prevalence of headache among ICU nurses (19.3\%), which was proven to be partly due to protective glasses. Chest discomfort and palpitation, dyspnea, nausea, and dizziness were reported as other common symptoms among their population [22]. In another study on 526 first-line HWs consisting of physicians and nurses, the general prevalence rate of skin damage caused by enhanced infection-prevention equipment was reported to be considerably high (97.0\%). Skin damage was $83.1 \%$ for nasal bridge, $78.7 \%$ for cheeks, $74.5 \%$ for hands, and $57.2 \%$ for forehead. Additionally, they reported that HWs wearing personal protective devices (N95 masks and goggles) for more than 6 hours had higher risks of skin damage at contact sites compared to those who had less exposure time [14]. Moreover, a study among Singaporean and Indian HWs revealed that headache $(31.9 \%)$, throat pain $(33.6 \%)$, and lethargy $(26.6 \%)$ were the more prevalent symptoms [26]. These findings demonstrated a significantly high prevalence of a variety of physical symptoms among nurses, for which PPE was a central causing factor.

\subsection{Moderators to mitigate nurses' challenges}

The scope of the reviewed articles not only included challenges but also many factors that could 
benefit nurses and mitigate the adversity of their novel working conditions. Organizational and social support, training, knowledge, and attitude were among the prominent moderators to shield against their adversity.

\subsubsection{Organizational and social support}

Based on the evidence, nurses identified multiple support systems to be significantly beneficial, including their hospitals, colleagues, families, friends, and society $[6-8,25]$. Nurses in the study by Liu et al. reasoned that with strong logistical support from their organization, they had a sense of safety and trust toward their hospital [6]. In a similar vein, a survey on 5062 HWs showed that "provision of adequate logistical support and accommodation by hospitals" was a significant determinant of stress $(P<.001)$, anxiety $(P<.001)$, and depression $(P<.001)$ [25]. Logistical support may include providing medical protective supplies, accommodations, transportation, food, medicines, and subsidies. For instance, many HWs $(71 \%)$ believed that "receiving free lunch and milk tea prepared by the hospital for frontline staff" always or often reduced their stress levels. In the same study, most HWs claimed that tangible support such as availability of guidelines for controlling infection or recognition of their efforts by the hospital were other facilitators that could help them in performing their job and lowering their stress [8]. Evidently, by providing tangible and intangible support, hospitals could play a key role in arming their nurses to fight the current battle.

With regard to social support, various articles (two qualitative studies and five surveys) mentioned the protecting nature of receiving support from colleagues, family, or friends [6-8, 25, 29]. Sun et al. [7] demonstrated that nurses who cared for and helped each other and showed support for stress relief in challenging situations felt that collective power and team cohesion were stronger; concisely communicated by a nurse: "Many colleagues called me to encourage me and I felt that there were many people who cared about me". They also showed that "receiving support from their families" was a significant support emphasized by nurses. These results were supported in another study [6], where nurses stated that "talking to their significant others about their work experiences" was also helpful as another form of support. Benefits of support by family and colleagues were also reported in three survey studies carried out on HWs in general. Zhu et al. found that living with family members was a positive protective factor against psychological disturbances, while "feeling of being avoided by family members and friends" was a factor leading to stress, anxiety, and depression. In a similar vein, Xiao et al. [29] demonstrated that a low social support score was closely related to the occurrence of stress, anxiety, and insomnia. In a study by Cai et al., $88 \%$ of nurses reported that chatting with family and friends alleviated their stress levels [8]. The literature supports the fact that social support can have a positive effect on adverse psychological burdens of nursing, helping them tackle difficult situations. It is noteworthy that all the above-mentioned studies regarding support were from China, and no similar studies from other regions were published yet.

\subsubsection{Training, knowledge and attitude}

Nurses are the backbone of the health system, and being at the risk of infection is a critical challenge not only for them, but for their organization and society. To address this challenge, four survey studies investigated the effect of knowledge and attitude about the Covid-19 pandemic on HWs. Two of the studies were from China [17, 34] and the two remaining were from Vietnam [35] and Pakistan [19]. Zhou et al. argued that knowledge was a prerequisite for establishing prevention beliefs and forming positive attitudes, which, in turn, leads to proper practice [17]. Moreover, they found a significant relationship between COVID-19 knowledge and HWs' attitude, i.e. the greater the knowledge of HWs, the more selfassured they were in overcoming obstacles (OR: 1.41; CI: 95\%). They concluded that teaching necessary knowledge should be organized by considering different factors (work experience, educational attainment, etc.). In another study on psychiatry nurses, training was revealed to be an independent variable associated with a greater willingness to care for COVID-19 patients. Nurses receiving advanced training regarding COVID-19 were significantly more enthusiastic about caring for patients [34]. Additionally, Saqlain et al. demonstrated that sufficient knowledge not only was associated with good attitudes, but also led to better precautionary practices [19]. It was also revealed in some other studies $[19,35]$ that although most HWs had sufficient knowledge and good attitude toward COVID-19, there were discrepancies among occupations, indicating that nurses had the lowest knowledge level compared to doctors or pharmacists. According to the above studies, knowledge is an essential factor to fuel attitude and willingness of nurses, and also, to inspire appropriate precautionary practice. 


\section{Discussion}

During the early stages of the current pandemic, our study sought to identify emerging nursing challenges by conducting a narrative review of the existing literature. We primarily intended to demonstrate what challenges nurses faced by examining highly credible research. To this end, 22 articles were included, the majority of which were survey studies from China. Synthesizing the studies, we identified four overarching themes including 1 . Being physically and mentally drained in the face of fear and uncertainty, 2. Shortage of personal protective equipment and usability issues, 3. Psychosomatic disturbances among nurses, and 4. Moderators to mitigate nurses' challenges.

By the time this review was conducted, there was as yet no cure for COVID-19, and like other new infectious diseases (e.g., Ebola), patient care was dominantly "supportive nursing care" [36]. Consequently, the pandemic transformed the profession of nursing into a challenging entity, pressuring nurses physically and mentally, as they worked long hours nursing highly demanding patients to compensate for the existing shortage of the manpower. On top of that, nurses not only had to cure the disease, but also needed to boost the morale of anxious patients, which, in turn, cost them emotionally. In the previous pandemics (i.e., MERS and H1N1 influenza), same observations were reported, where nurses were under heavy workload, mainly due to the seriousness of the diseases or a staffing shortage [37-39].Such overstretchings can lead to burnout and reduced quality of care $[37,40]$. To counter this situation, administrators must be ready beforehand for the possible system overload during grueling times (i.e., block booking contract or agency nurses in advance to be of help in a pandemic emergency). It is also suggested to limit annual leave during this time and increase the ancillary staff level to manage extra cleaning duties and extra support required for repositioning of patients [37].

In addition to laborious duties of nursing, what truly impacted nurses and their efforts were uncertainty and fear of the disease which had similarities to the reports of the previous pandemics $[37,38$, $41,42]$. It is well-known that fear can negatively impact effectiveness, or even, lead to the avoidance of patients [43]. Although a certain level of such fear is inevitable and cannot be entirely eliminated, it is suggested that by providing HWs with adequate PPE, sharing information about their quality, and providing necessary training on how to use them, fear can be largely diminished [38, 44].

PPE shortage was another problem highlighted in the current pandemic. The scale of the bio disaster was so vast that disabled many health systems. It is recommended to make institutional plans in advance to supply protective equipment when there is a surge in its demand [45]. Non user-friendly PPE and long exposure to them were other sources of dissatisfaction among nurses, which led to many serious physical distresses including heat and sweat, headache, skin problems, and lethargy. Regrettably, inferior usability of PPE was a recurrent issue common to the recent pandemics, which has remained to be addressed [37, $42,46,47]$. In their study during the human swine influenza outbreak in Hong Kong, Lam and Hung [46] regarded PPE uncomfortable and time-consuming. Similarly, PPE usage in Australia was reported to be irritating and created unnecessary duties during the outbreak [37]. Any discomfort and annoyance of PPE is undesirable since it can undermine the compliance of HWs in using protective equipment [46], and consequently, may pose a threat to the public health [48]. In this concern, it is of great significance that medical equipment companies design PPE according to the ergonomics principle and obtain feedback from nurses on their usability to design more user-friendly equipment.

Not surprisingly, HWs, especially nurses, experienced high levels of stress, anxiety, and depression during the pandemic. This observation is similar to that of nurses who cared for Severe Acute Respiratory Syndrome (SARS), Middle East Respiratory Syndrome (MERS), or Human Swine Influenza (HIS) patients, where they expressed high levels of stress, anxiety, and psychological trauma during and after caring for the patients [46, 47, 49]. A study during the MERS outbreak showed that psychological strains could adversely affect nurses' intention, professionalism [50], and psychological morale [51, 52]. Therefore, a system is needed to help manage nurses' psychological disturbances and provide necessary support. Additionally, a mental health and stress control program is needed for nurses, especially frontline staff, to prevent psychological trauma in them [47]. Rajkumar presented a number of therapeutic interventions and strategies that can be considered when designing mental health services [5].

Studies reported various essential mediators to combat challenges and difficulties during the pandemic. Among them, receiving proper support from organizations, colleagues, and relatives including 
family was emphasized in the studies. Studies during the past epidemics have shown that poor social support from family, colleagues, and bosses is related to adverse outcomes including stress, burnout, dissatisfaction, and intention to leave [42, 47, 53-55]. Two significant aspects of organizational support were adequate logistic provision and recognition from nurses. Similar to other studies, it was found that these two factors could act as significant facilitators to nurses' well-being $[42,56,57]$. Accordingly, during a pandemic, it is critical to protect the nursing community by evoking appropriate support from the right people through social campaigns or organizational policies. To enhance the impact of such movements, it is suggested to provide social support by taking into account national and cultural factors [58, 59].

Training, knowledge, and attitude were other identified moderating factors that could ease nursing challenges. Possessing the necessary knowledge was reported to bring about a positive attitude toward obstacles and lead to the right practice. Moreover, proper training to enhance such knowledge was revealed to facilitate this process. The significance of training during pandemics has been highlighted in the literature [60, 61]. Possessing necessary knowledge should be of great concern during an outbreak, in which there is a turbulent flow of information, and information overload is an obstacle to providing proper care $[46,50,62,63]$. Effective training including evidence-based knowledge and clinical skills applicable to patient care should target nurses in particular, since they were reported to be less knowledgeable compared to other HWs.

\section{Conclusion and implications for practice}

This review sought to underline major nursing challenges in the midst of the COVID-19 pandemic. In the face of all deficiencies, nurses experienced a severe situation, being overstretched to shoulder the great responsibility of providing care for demanding COVID-19 patients, during which a significant amount of psychological and physical pain was inflicted to them. However, a lot that can be done to ameliorate the situation. First, administrators should be ready in advance for an unpredictable disaster by considering back up resources including people and equipment. They should also set up systems to monitor and support nurses' mental status during and after the pandemic. Second, a significant proportion of nursing distress can be mitigated by providing them with adequate user-friendly (ergonomic) PPE, the design of which has been informed by nurses' feedback. Third, administrators should support nurses by effective training, proper logistics, and recognizing their efforts during the pandemic. However, supporting nurses is not only limited to their respective organizations, and the society at large, especially their families and coworkers, can play a major role in their support.

\section{Limitations and future directions}

There are some limitations in the current review. First, while every effort was made to keep the focus on nurses, there were several studies, in which we could not distinguish between the results of nurses and those of other HWs. However, it could not have imposed a threat to the interpretation of the result since in all cases, the absolute proportion of the population was nurses. Second, this study was conducted almost immediately after the pandemic. Therefore, the reviewed studies provided some initial but limited evidence about the plethora of challenges experienced by nurses during the COVID-19 pandemic. Future studies may wish to explore the lived experience of nurses since they can provide rich data with regard to the broad spectrum of issues from the field. Such studies may provide valuable information, helping to carry out further quantitative studies. Third, all the studies were from Asia, with the majority of them being from China, which makes the generalizability of the findings limited. Evidently, there was a need for studies from other regions, especially Western countries.

\section{Conflict of interest}

None to report.

\section{References}

[1] WHO. WHO Director-General's opening remarks at the media briefing on COVID-19-11 March 20202020 [Available from: https://www.who.int/dg/speeches/detail.

[2] Worldometers. coronavirus pandemic 2020 [updated 6/9/2020. Available from: https://www.worldometers.info/ coronavirus.

[3] Sarailoo M, Matin S, Vosoughi M, Dargahi A, Gholizadeh $\mathrm{H}$, Rajabi Damavandi M, et al. Investigating the relationship between occupation and SARS-CoV2. Work. (Preprint): $1-6$. 
[4] Garosi E, Khosravi Danesh M, Mazloumi A. Nurses and Coronavirus: Challenges and Consequences. Iran Occupational Health. 2020;17(1):1-6.

[5] Rajkumar RP. COVID-19 and mental health: A review of the existing literature. Asian J Psychiatr. 2020:102066.

[6] Liu Q, Luo D, Haase JE, Guo Q, Wang XQ, Liu S, et al. The experiences of health-care providers during the COVID-19 crisis in China: a qualitative study. Lancet Glob Health. 2020.

[7] Sun N, Shi S, Jiao D, Song R, Ma L, Wang H, et al. A qualitative study on the psychological experience of caregivers of COVID-19 patients. American Journal of Infection Control. 2020.

[8] Cai H, Tu B, Ma J, Chen L, Fu L, Jiang Y, et al. Psychological Impact and Coping Strategies of Frontline Medical Staff in Hunan Between January and March 2020 During the Outbreak of Coronavirus Disease 2019 (COVID-19) in Hubei, China. Medical science monitor: international medical journal of experimental and clinical research. 2020;26:e924171-1.

[9] Hick JL, Hanfling D, Wynia MK, Pavia AT. Duty to plan: health care, crisis standards of care, and novel coronavirus SARS-CoV-2. NAM Perspectives. 2020.

[10] Wang J, Zhou M, Liu F. Reasons for healthcare workers becoming infected with novel coronavirus disease 2019 (COVID-19) in China. Journal of Hospital Infection. 2020;105(1):100-1.

[11] Shanafelt T, Ripp J, Trockel M. Understanding and addressing sources of anxiety among health care professionals during the COVID-19 pandemic. JAMA. 2020.

[12] Zarocostas J. How to fight an infodemic. The Lancet. 2020;395(10225):676.

[13] Ferrari R. Writing narrative style literature reviews. Medical Writing. 2015;24(4):230-5.

[14] Lan J, Song Z, Miao X, Li H, Li Y, Dong L, et al. Skin damage among health care workers managing coronavirus disease-2019. J Am Acad Dermatol. 2020;82(5):1215-6.

[15] Vaismoradi M, Jones J, Turunen H, Snelgrove S. Theme development in qualitative content analysis and thematic analysis. 2016.

[16] Miles MB, Huberman AM, Saldaña J. Qualitative data analysis: A methods sourcebook: Sage publications; 2018.

[17] Zhou M, Tang F, Wang Y, Nie H, Zhang L, You G, et al. Knowledge, attitude and practice regarding COVID-19 among health care workers in Henan, China. Journal of Hospital Infection. 2020.

[18] Mo Y, Deng L, Zhang L, Lang Q, Liao C, Wang N, et al. Work stress among Chinese nurses to support Wuhan for fighting against the COVID-19 epidemic. Journal of Nursing Management. 2020.

[19] Saqlain M, Munir MM, ur Rehman S, Gulzar A, Naz S, Ahmed Z, et al. Knowledge, attitude, practice and perceived barriers among healthcare professionals regarding COVID-19: A Cross-sectional survey from Pakistan. Journal of Hospital Infection. 2020.

[20] Zhang X, Jiang Z, Yuan X, Wang Y, Huang D, Hu R, et al. Nurses reports of actual work hours and preferred work hours per shift among frontline nurses during coronavirus disease 2019 (COVID-19) epidemic: A cross-sectional survey. International Journal of Nursing Studies. 2020: 103635.

[21] Liu C, Yang Y-z, Zhang XM, Xu X, Dou Q-L, Zhang W-W. The prevalence and influencing factors for anxiety in medical workers fighting COVID-19 in China: A cross-sectional survey. medRxiv. 2020:2020.03.05.20032003.
[22] Yifan T, Ying L, Chunhong G, Jing S, Rong W, Zhenyu $\mathrm{L}$, et al. Symptom Cluster of ICU nurses treating COVID19 pneumonia patients in Wuhan, China. J Pain Symptom Manage. 2020.

[23] Yin X, Zeng L. A study on the psychological needs of nurses caring for patients with coronavirus disease 2019 from the perspective of the existence, relatedness, and growth theory. International Journal of Nursing Sciences. 2020.

[24] Ong JJ, Bharatendu C, Goh Y, Tang JZ, Sooi KW, Tan YL, et al. Headaches Associated with Personal Protective Equipment-A Cross-sectional Study Amongst Frontline Healthcare Workers During COVID-19 (HAPPE Study). Headache: The Journal of Head and Face Pain. 2020.

[25] Zhu Z, Xu S, Wang H, Liu Z, Wu J, Li G, et al. COVID-19 in Wuhan: Immediate Psychological Impact on 5062 Health Workers. medRxiv. 2020.

[26] Chew NW, Lee GK, Tan BY, Jing M, Goh Y, Ngiam $\mathrm{NJ}$, et al. A multinational, multicentre study on the psychological outcomes and associated physical symptoms amongst healthcare workers during COVID-19 outbreak. Brain, behavior, and immunity. 2020.

[27] Huang Y, Zhao N. Generalized anxiety disorder, depressive symptoms and sleep quality during COVID-19 outbreak in China: a web-based cross-sectional survey. Psychiatry Res. 2020:112954.

[28] Lai J, Ma S, Wang Y, Cai Z, Hu J, Wei N, et al. Factors associated with mental health outcomes among health care workers exposed to coronavirus disease 2019. JAMA network open. 2020;3(3):e203976-e.

[29] Xiao H, Zhang Y, Kong D, Li S, Yang N. The effects of social support on sleep quality of medical staff treating patients with coronavirus disease 2019 (COVID-19) in January and February 2020 in China. Medical Science Monitor: International Medical Journal of Experimental and Clinical Research. 2020;26:e923549-1.

[30] Jin Y-H, Huang Q, Wang Y-Y, Zeng X-T, Luo L-S, Pan Z$\mathrm{Y}$, et al. Perceived infection transmission routes, infection control practices, psychosocial changes, and management of COVID-19 infected healthcare workers in a tertiary acute care hospital in Wuhan: a cross-sectional survey. Military Medical Research. 2020;7(1):1-13.

[31] Liu C-Y, Yang Y-z, Zhang X-M, Xu X, Dou Q-L, Zhang $\mathrm{W}-\mathrm{W}$. The prevalence and influencing factors for anxiety in medical workers fighting COVID-19 in China: A cross-sectional survey. Available at SSRN 3548781. 2020.

[32] Kang L, Ma S, Chen M, Yang J, Wang Y, Li R, et al. Impact on mental health and perceptions of psychological care among medical and nursing staff in Wuhan during the 2019 novel coronavirus disease outbreak: A cross-sectional study. Brain, behavior, and immunity. 2020.

[33] Wu Y, Wang J, Luo C, Hu S, Lin X, Anderson AE, et al. A comparison of burnout frequency among oncology physicians and nurses working on the front lines and usual wards during the COVID-19 epidemic in Wuhan, China. J Pain Symptom Manage. 2020.

[34] Shi Y, Wang J, Yang Y, Wang Z, Wang G, Hashimoto K, et al. Knowledge and attitudes of medical staff in Chinese psychiatric hospitals regarding COVID-19. Brain, Behavior, \& Immunity-Health. 2020:100064.

[35] Giao H, Han NTN, Van Khanh T, Ngan VK, Van Tam V, Le An P. Knowledge and attitude toward COVID-19 among healthcare workers at District 2 Hospital, Ho Chi Minh City. Asian Pac J Trop Med. 2020;13. 
[36] McGillis Hall L, Kashin J. Public understanding of the role of nurses during Ebola. Journal of Nursing Scholarship. 2016;48(1):91-7.

[37] Corley A, Hammond NE, Fraser JF. The experiences of health care workers employed in an Australian intensive care unit during the H1N1 Influenza pandemic of 2009: a phenomenological study. International Journal of Nursing Studies. 2010;47(5):577-85.

[38] Kang HS, Son YD, Chae SM, Corte C. Working experiences of nurses during the Middle East respiratory syndrome outbreak. Int J Nurs Pract. 2018;24(5):e12664.

[39] Shih F-J, Gau M-L, Kao C-C, Yang C-Y, Lin Y-S, Liao $\mathrm{Y}-\mathrm{C}$, et al. Dying and caring on the edge: Taiwan's surviving nurses' reflections on taking care of patients with severe acute respiratory syndrome. Appl Nurs Res. 2007;20(4):171-80.

[40] Scott LD, Rogers AE, Hwang W-T, Zhang Y. Effects of critical care nurses' work hours on vigilance and patients' safety. Am J Crit Care. 2006;15(1):30-7.

[41] Erland E, Dahl B. Midwives' experiences of caring for pregnant women admitted to Ebola centres in Sierra Leone. Midwifery. 2017;55:23-8.

[42] Ives J, Greenfield S, Parry JM, Draper H, Gratus C, Petts JI, et al. Healthcare workers' attitudes to working during pandemic influenza: a qualitative study. BMC Public Health. 2009;9(1):56

[43] Imai T, Takahashi K, Hoshuyama T, Hasegawa N, Lim M$\mathrm{K}$, Koh D. SARS risk perceptions in healthcare workers, Japan. Emerging Infectious Diseases. 2005;11(3):404.

[44] Bell SA, Munro-Kramer ML, Eisenberg MC, Williams G, Amarah P, Lori JR. "Ebola kills generations": Qualitative discussions with Liberian healthcare providers. Midwifery. 2017;45:44-9.

[45] Stirling B, Hatcher J, Harmston J. Communicating the changing role of a nurse in an epidemic: The example of the MERS-CoV outbreak in Saudi Arabia. Journal of Healthcare Communications. 2017;2(3):30.

[46] Lam KK, Hung SYM. Perceptions of emergency nurses during the human swine influenza outbreak: A qualitative study. Int Emerg Nurs. 2013;21(4):240-6.

[47] Kim Y. Nurses' experiences of care for patients with Middle East respiratory syndrome-coronavirus in South Korea. American Journal of Infection Control. 2018;46(7):781-7.

[48] Loeb M, McGeer A, Henry B, Ofner M, Rose D, Hlywka T, et al. SARS among critical care nurses, Toronto. Emerging Infectious Diseases. 2004;10(2):251.

[49] Maunder RG, Lancee WJ, Balderson KE, Bennett JP, Borgundvaag B, Evans S, et al. Long-term psychological and occupational effects of providing hospital healthcare during SARS outbreak. Emerging Infectious Diseases. 2006;12(12):1924.

[50] Oh N, Hong N, Ryu DH, Bae SG, Kam S, Kim K-Y. Exploring nursing intention, stress, and professionalism in response to infectious disease emergencies: The experience of local public hospital nurses during the 2015 MERS outbreak in South Korea. Asian Nursing Research. 2017;11(3):230-6
[51] Imai $T$, Takahashi $\mathrm{K}$, Todoroki $\mathrm{M}$, Kunishima $\mathrm{H}$, Hoshuyama T, Ide R, et al. Perception in relation to a potential influenza pandemic among healthcare workers in Japan: implications for preparedness. Journal of Occupational Health. 2008;50(1):13-23.

[52] Wong TY, Koh GC, Cheong SK, Lee HY, Fong YT, Sundram $\mathrm{M}$, et al. Concerns, perceived impact and preparedness in an avian influenza pandemic-a comparative study between healthcare workers in primary and tertiary care. AnnalsAcademy Of Medicine Singapore. 2008;37(2):96.

[53] Kim JS, Choi JS. Factors influencing emergency nurses' burnout during an outbreak of Middle East Respiratory Syndrome Coronavirus in Korea. Asian Nursing Research. 2016;10(4):295-9.

[54] Chung BPM, Wong TKS, Suen ESB, Chung JWY. SARS: caring for patients in Hong Kong. Journal of Clinical Nursing. 2005; 14(4):510-7.

[55] CHOI SPP, Cheung K, PANG SMC. Attributes of nursing work environment as predictors of registered nurses' job satisfaction and intention to leave. Journal of Nursing Management. 2013;21(3):429-39.

[56] Maunder R, Hunter J, Vincent L, Bennett J, Peladeau N, Leszcz M, et al. The immediate psychological and occupational impact of the 2003 SARS outbreak in a teaching hospital. CMAJ. 2003;168(10):1245-51.

[57] Danesh MK, Garosi E, Mazloumi A, Najafi S. Identifying factors influencing cardiac care nurses' work ability within the framework of system engineering initiative for patient safety. Work. 2020(Preprint):1-9.

[58] Tzeng H-M, Yin C-Y. Nurses' fears and professional obligations concerning possible human-to-human avian flu. Nursing Ethics. 2006;13(5):455-70.

[59] Brug J, Aro AR, Oenema A, De Zwart O, Richardus JH, Bishop GD. SARS risk perception, knowledge, precautions, and information sources, the Netherlands. Emerging Infectious Diseases. 2004;10(8): 1486.

[60] Leiba A, Goldberg A, Hourvitz A, Amsalem Y, Aran A, Weiss G, et al. Lessons learned from clinical anthrax drills: evaluation of knowledge and preparedness for a bioterrorist threat in Israeli emergency departments. Annals of Emergency Medicine. 2006;48(2):194-9. e2.

[61] Vinson E. Managing bioterrorism mass casualties in an emergency department: lessons learned from a rural community hospital disaster drill. Disaster Management \& Response. 2007;5(1):18-21.

[62] Leigh L, Taylor C, Glassman T, Thompson A, Sheu JJ. A Cross-Sectional Examination on the Factors Related to Emergency Nurses' Motivation to Protect Themselves against an Ebola Infection. Journal of Emergency Nursing. 2020.

[63] Do Rosário Costa N, Bellas H, da Silva PRF, de Carvalho PVR, Uhr D, Vieira C, et al. Community health workers' attitudes, practices and perceptions towards the COVID19 pandemic in brazilian low-income communities. Work. (Preprint):1-9. 